\title{
RELATIONSHIP BETWEEN NURSING AND DENTISTRY IN PATIENT CARE IN INTENSIVE CARE UNIT: AN INTEGRATIVE LITERATURE REVIEW
}

Gabriel Lucas Pereira Guimarães ${ }^{*}{ }^{凶}$ (iD), Giovanna Nascimento Mendes ${ }^{2}$ (D), Quéren Gabriele Cunha Silva ${ }^{3}$ (D), Samylly dos Santos Santana 4(D), Nahida Sarhan de Lima ${ }^{5}$ iD , Gabriele Angélica Silva Santos ${ }^{6}$ (D), Franciel Alves Nascimento 7 (iD), Marcela Barbosa Peixoto ${ }^{8}$ (D), Tiago José Silva Oliveira $9{ }^{9}$ (D), Ivair Tavares Junior 10

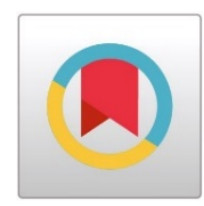
iD

\footnotetext{
${ }^{* 1}$ Secretarial Technologist, Post-graduate student in Administration and Auditing in Health Services from Faculdade Dom Alberto, Graduating in Nursing from Adventist College of Bahia, Cachoeira-BA, Brazil

2, 5, 6 Dental Surgeon from Adventist College of Bahia, Cachoeira-BA, Brazil

3,4 Graduating in Nursing from Adventist College of Bahia, Cachoeira-BA, Brazil

7 Graduating in Dentistry from Adventist College of Bahia, Cachoeira-BA, Brazil

${ }^{8}$ Nurse Specialist in Intensive Nursing-ICU. Nursing and RT Coordinator of the ICU of Hospital and maternity Luiz Argolo - SAJ / BA. Nursing professor of Adventist College of Bahia, Cachoeira-BA, Brazil

9 Dental Surgeon, Master in Public Health (Epidemiology). Professor of Dentistry of Adventist College of Bahia, Cachoeira-BA, Brazil

${ }^{10}$ Dental Surgeon, Master in dental clinic and Specialist in implantology and Professor of Dentistry of Adventist College of Bahia, Cachoeira-BA, Brazil
}

DOI: https://doi.org/10.29121/granthaalayah.v9.i2.2021.3326

Article Type: Research Article

Article Citation: Gabriel Lucas Pereira Guimarães, Giovanna Nascimento Mendes, Quéren Gabriele Cunha Silva, Samylly dos Santos Santana, Nahida Sarhan de Lima, Gabriele Angélica Silva Santos, Franciel Alves Nascimento, Marcela Barbosa Peixoto, Tiago José Silva Oliveira, and Ivair Tavares Junior. (2021). RELATIONSHIP BETWEEN NURSING AND DENTISTRY IN PATIENT CARE IN INTENSIVE CARE UNIT: AN INTEGRATIVE LITERATURE REVIEW. International Journal of Research GRANTHAALAYAH, 9(2), 55-63. https://doi.org/10.29121/granthaalayah.v9.i2.2021.3326

Received Date: 29 January 2021

Accepted Date: 23 February 2021

Keywords:

Ventilator-Associated Pneumonia

Chlorhexidine

Oral Hygiene

Intensive Care Unit 
Relationship Between Nursing and Dentistry in Patient Care in Intensive Care Unit: An Integrative Literature Review

\section{ABSTRACT}

Objective: To highlight what has been published in the scientific literature on care strategies and protocols used by the nursing team regarding oral health and how dentistry can contribute, guide and improve the care process for inpatients.

Methodology: Integrative literature review performed with original articles, available in full, indexed between 2015 and 2020 in the PubMed, LILACS, SciELO and Google academic databases.

Results: Eight studies were selected between 2015 and 2020 through critical synthesis that deal with oral care in hospitalized patients.

Final considerations: The relationship between dentistry and nursing with oral care and the inclusion of the Dental Surgeon in the health team, contribute to the prevention and treatment of oral conditions, leading to the synergy of the health team, reducing risk factors, enabling a healing process and reducing possible nosocomial infections in the hospital environment.

\section{INTRODUCTION}

The oral cavity is home to one of the highest concentrations of microorganisms in the human body, [1] aerobic and anaerobic bacteria, in addition to the existing dental biofilm, are etiological agents for caries and periodontal diseases, making it a suitable set for the installation of opportunistic infections, symptoms painful, and infectious foci, when in a weak state of health, contributes to the extension of the hospitalization period, being also one of the factors for possible diseases and injuries to the patient. [2]

Among cares necessary for a critical patient is oral health, these cares are important tools for the prevention and control of infections, through antibacterials and instruments for periodontal cleaning. [3] The nursing team performs oral care as it is essential for patient comfort, since oral health is inseparable as a whole. Knowledge of oral interactions with the patient's general condition is essential, especially in the Intensive Care Unit (ICU). [4]

In the ICU environment, hospitalized patients are exposed to pathogens, which in turn can increase the likelihood of pneumonia and injuries the patient's health. [5] Due to the weakened state of health, patients need tubes, and depending on the clinical picture, they will need mechanical ventilation. When intubated they cannot develop self-care (deficit in self-care syndrome), this includes oral hygiene. The nursing team, which in turn is responsible for daily hygiene and through the evolution (physical examination, etc.) of the patient will collect data on the state of the oral cavity regarding inflammations, edema, injuries and treatments in use. [6] Also through the systematization of nursing care (SAE) the professional will contribute to patient care, favoring the identification of situations and diseases, ensuring assistance in the care process through the development of action plans aimed at the patient's recovery. [7]

It is up to the nurse to provide adequate assistance through protocols and continuing education or the multidisciplinary relationship of a dental professional with the health team, since the mouth of patients admitted to the ICU can serve as an important source for respiratory pathogens associated with nosocomial pneumonia. [8] Therefore, an oral assessment of patients in these conditions is necessary, since the oral cavity is one of the sources of contamination. Therefore, the Dental Surgeon included in the multidisciplinary team has the fundamental role of diagnosis, treatment, general and palliative care of the oral cavity, which will lead to greater patient comfort and more safety and less chance of infections. [9]

In the cardiac ICU, for example, it is recommended that the surgical procedures performed undergo evaluation and, if necessary, prior dental treatment, due to the risk of heart infection resulting from oral conditions, cavities, pulpitis and periodontitis. [10] Therefore, prior dental preparation, in addition to therapeutic procedures and guidance for pre- and post-operative to the patient / caregiver / family / about oral hygiene care and the need to change harmful habits for oral health, prevent infections of patients both in the hospital / outpatient setting and in intensive care units. [11]

It should be noted that the presence of the Dental Surgeon is not mandatory in the health team that assists in hospital admissions despite the need and importance of the professional within the ICU, in addition to this, the presidential veto in 2019 to the PLC project 34 / 2013 that would make the provision of dental care mandatory to patients in hospitalization. [12] The non-mandatory presence of a specialized professional in the multidisciplinary hospital team for oral care has become a possible barrier to the advancement of respiratory infections control, since 
Gabriel Lucas Pereira Guimarães, Giovanna Nascimento Mendes, Quéren Gabriele Cunha Silva, Samylly dos Santos Santana, Nahida Sarhan de Lima, Gabriele Angélica Silva Santos, Franciel Alves Nascimento, Marcela Barbosa Peixoto, Tiago José Silva Oliveira, and Ivair Tavares Junior

the presence of the dentist would lead to a better construction and implementation of protocols of oral hygiene for the health team, evaluation and diagnosis of infectious foci in the oral cavity by the Dental Surgeon, avoiding damage to general health. [13]

Based on this scenario, the guiding question of this study is: What are the benefits of the nursing / dentistry relationship in patient care in the intensive care unit? The objective of this research is to highlight what has been published in the scientific literature on care strategies and protocols used by the nursing team with regard to oral health and how dentistry can contribute, guide and improve the process of caring for patients in the ICU.

\section{METHODS}

The integrative literature review was carried out by means of bibliographic search in four databases: PubMed, LILACS, SciELO and Google Scholar. Original articles indexed between 2015 and 2020 were included, studies in the hospital environment were chosen, with a sample number $\geq 20$. Articles written in Portuguese and English were selected. For research, descriptors English in MeSH and Portuguese in DeCS were used: Pneumonia (pneumonia) ventilator-associated (fan-associated); Chlorhexidine (chlorhexidine); Oral hygiene; Intensive care units; (intensive care unit).

The integrative review seeks to debate the knowledge on a specific topic since it is aimed at identifying, conducting analyzes and providing a synthesis of results from a given subject in order to contribute beneficially to the provision of care to patients in a critical way aiming at quality of care in the light of the literature scientific. [14]

The studies were selected by relevance to the topic, by reading the title and summary, duplicate references were excluded. The studies went through two screenings, according to the inclusion criteria: articles available in full; published in English or Portuguese; that addressed oral hygiene techniques; relationship between nursing and dentistry; oral care by the nursing team.

From the selected databases, it was possible to read the title of 46 articles and selected those that best met the theme proposed here. Then, the abstracts were read, with 14 being selected that met the inclusion criteria. Afterwards, a thorough and careful reading of 10 articles was carried out, in the end only 08 articles were selected. The data obtained were organized and analyzed critically by comparing them with the scientific literature. Below is the flowchart of the methodological path (Figure 01).

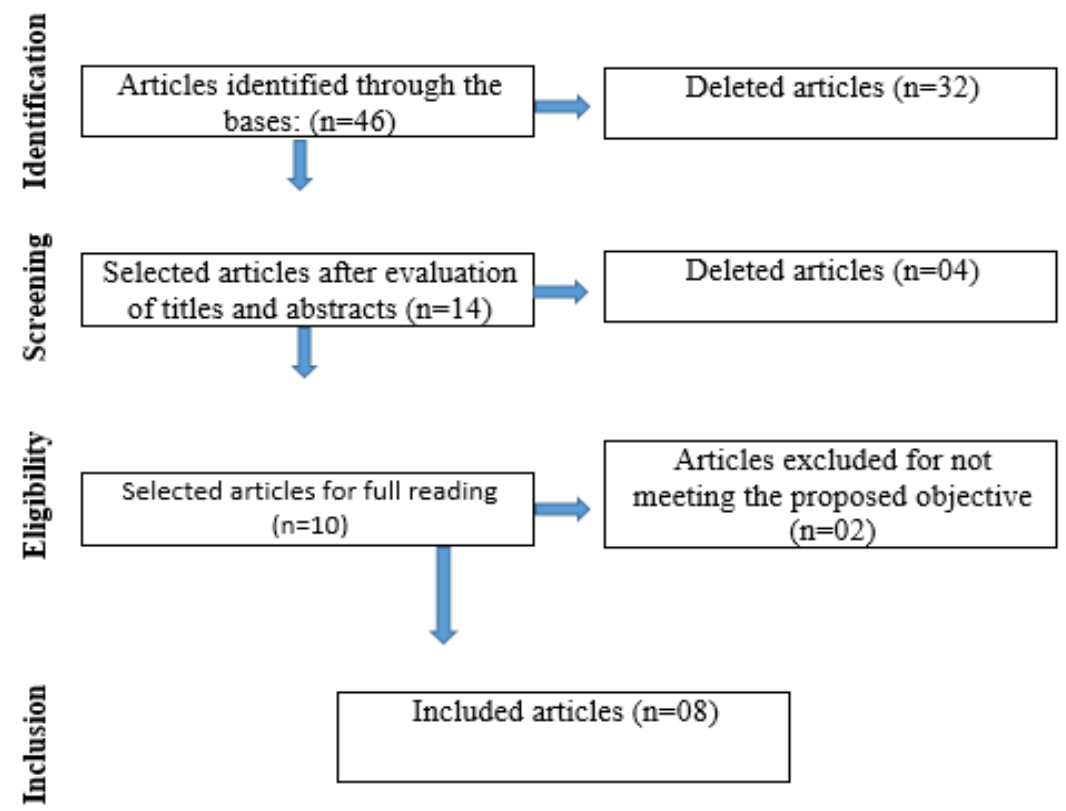

Figure 01: Flowchart of research information in the databases mapping the number of identified, included and excluded records, and the reasons for exclusions, according to the PRISMA Flow Diagram. Cachoeira, BA, Brazil, 2020. 


\section{RESULTS}

Chart 1: Details of the articles included in the review. Cachoeira, BA, Brazil, 2020.

\begin{tabular}{|c|c|c|c|c|c|}
\hline № & Authors & Theme & Population & Results / Conclusion & Journal / Year \\
\hline 1 & $\begin{array}{c}\text { Blum DFC, } \\
\text { Silva JAS, } \\
\text { Baeder FM, } \\
\text { et al. [15] }\end{array}$ & $\begin{array}{l}\text { The role of } \\
\text { Dentistry in } \\
\text { intensive care } \\
\text { units in Brazil }\end{array}$ & $\begin{array}{c}4.569 \\
\text { professionals } \\
\text { from different } \\
\text { specialties } \\
\text { working in the } \\
\text { ICU. } \\
\end{array}$ & $\begin{array}{l}\text { Oral hygiene methods } \\
\text { varied widely among the } \\
\text { intensive care units } \\
\text { surveyed }\end{array}$ & $\begin{array}{l}\text { Revista } \\
\text { Brasileira de } \\
\text { Terapia } \\
\text { Intensiva. } \\
\text { (2018) }\end{array}$ \\
\hline 2 & $\begin{array}{c}\text { Ory J, } \\
\text { Raybaud E, } \\
\text { Chabanne R, } \\
\text { et al. [16] }\end{array}$ & $\begin{array}{l}\text { Protocols for } \\
\text { oral hygiene in } \\
\text { ICU patients }\end{array}$ & $\begin{array}{l}2.030 \text { intubated } \\
\text { patients } \\
\text { admitted to the } \\
\text { adult ICU } \\
\text { different } \\
\text { specialties } \\
\end{array}$ & $\begin{array}{l}\text { The implementation of a } \\
\text { simple protocol improves } \\
\text { the quality of oral care for } \\
\text { patients in the ICU and } \\
\text { decreased VAP rates }\end{array}$ & $\begin{array}{l}\text { American } \\
\text { Journal of } \\
\text { Infection } \\
\text { Control. } \\
\text { (2017) }\end{array}$ \\
\hline 3 & \begin{tabular}{|c|} 
Blum DFC, \\
Munaretto J, \\
Baeder FM, \\
et al. [17]
\end{tabular} & $\begin{array}{l}\text { Influence of the } \\
\text { presence of } \\
\text { dental } \\
\text { professionals in } \\
\text { oral health care } \\
\text { protocols in the } \\
\text { nursing team of } \\
\text { the intensive } \\
\text { care unit. } \\
\text { Survey study } \\
\end{array}$ & $\begin{array}{c}231 \text { team } \\
\text { members from } \\
\text { nine ICUs at } \\
\text { three hospitals } \\
\text { located in the } \\
\text { Southern Region } \\
\text { of Brazil. }\end{array}$ & $\begin{array}{l}\text { Most of them }(99.6 \%), \\
\text { participants agreed with } \\
\text { the importance of oral } \\
\text { care for patients in the } \\
\text { ICU, and } 88.3 \% \text { of the } \\
\text { team agreed that oral } \\
\text { health problems are } \\
\text { common in intensive } \\
\text { care. }\end{array}$ & $\begin{array}{l}\text { Revista } \\
\text { Brasileira de } \\
\text { Terapia } \\
\text { Intensiva. } \\
\text { (2017) }\end{array}$ \\
\hline 4 & $\begin{array}{c}\text { Feitosa DAS, } \\
\text { Souza HTN, } \\
\text { Alencar AM, } \\
\text { et al. [18] }\end{array}$ & $\begin{array}{l}\text { Perception of } \\
\text { professionals } \\
\text { working in the } \\
\text { ICU regarding } \\
\text { the importance } \\
\text { of oral health } \\
\text { practices. } \\
\end{array}$ & 20 individuals & $\begin{array}{l}\text { Professionals are } \\
\text { negligent regarding oral } \\
\text { hygiene, only to the } \\
\text { patient's hospitalization }\end{array}$ & $\begin{array}{c}\text { Revista da } \\
\text { Faculdade de } \\
\text { Odontologia. } \\
\text { Universidade } \\
\text { de Passo fundo. } \\
\text { (2019) }\end{array}$ \\
\hline 5 & $\begin{array}{c}\text { Oliveira LS, } \\
\text { Bernadino } \\
\text { IM, Silva JAL, } \\
\text { et al. [19] }\end{array}$ & $\begin{array}{l}\text { Knowledge and } \\
\text { practice of oral } \\
\text { hygiene control } \\
\text { in patients } \\
\text { admitted to } \\
\text { intensive care } \\
\text { units } \\
\end{array}$ & $\begin{array}{l}41 \text { health } \\
\text { professionals } \\
\text { working in the } \\
\text { ICU }\end{array}$ & $\begin{array}{l}\text { The need to develop and } \\
\text { expand teaching, research } \\
\text { and extension activities } \\
\text { related to Hospital } \\
\text { Dentistry in Dentistry } \\
\text { courses in Brazil is } \\
\text { evident. }\end{array}$ & $\begin{array}{c}\text { Revista da } \\
\text { ABENO. (2015) }\end{array}$ \\
\hline 6 & $\begin{array}{c}\text { Silva JL, O El } \\
\text { Kadre GD, } \\
\text { Kudo GA, et } \\
\text { al. [20] }\end{array}$ & $\begin{array}{c}\text { The oral } \\
\text { hygiene } \\
\text { technique is an } \\
\text { important factor } \\
\text { to maintain the } \\
\text { health and } \\
\text { comfort of } \\
\text { hospitalized } \\
\text { patients, given } \\
\text { the frequent } \\
\text { presence of oral }\end{array}$ & $\begin{array}{l}\text { The sample } \\
\text { consisted of } 45 \\
\text { patients } \\
\text { admitted to an } \\
\text { ICU who were } \\
\text { evaluated in } \\
\text { relation to the } \\
\text { oral biofilm } \\
\text { score index. }\end{array}$ & $\begin{array}{l}\text { Based on these results, it } \\
\text { is recommended that ICU } \\
\text { caregivers complete } \\
\text { relevant oral health } \\
\text { training programs. }\end{array}$ & $\begin{array}{c}\text { The Journal of } \\
\text { Contemporary } \\
\text { Dental Practice. } \\
\text { (2016) }\end{array}$ \\
\hline
\end{tabular}


Gabriel Lucas Pereira Guimarães, Giovanna Nascimento Mendes, Quéren Gabriele Cunha Silva, Samylly dos Santos Santana, Nahida Sarhan de Lima, Gabriele Angélica Silva Santos, Franciel Alves Nascimento, Marcela Barbosa Peixoto, Tiago José Silva Oliveira, and Ivair Tavares Junior

\begin{tabular}{|c|c|c|c|c|c|}
\hline & & $\begin{array}{l}\text { biofilm and } \\
\text { pathogens } \\
\text { caused by } \\
\text { mouth } \\
\text { breathing }\end{array}$ & & & \\
\hline 7 & $\begin{array}{c}\text { Matos } \\
\text { MPSO, Silva } \\
\text { RFG }[21]\end{array}$ & $\begin{array}{l}\text { The } \\
\text { effectiveness of } \\
\text { oral hygiene in } \\
\text { preventing } \\
\text { respiratory } \\
\text { diseases in } \\
\text { patients } \\
\text { admitted to the } \\
\text { Adult ICU of the } \\
\text { Emergency } \\
\text { Room } 28 \text { de } \\
\text { Agosto }\end{array}$ & $\begin{array}{l}58 \text { employees } \\
\text { participating in } \\
\text { this study }\end{array}$ & $\begin{array}{l}\text { It was verified the } \\
\text { number of times and in } \\
\text { the origin and practice of } \\
\text { performing the } \\
\text { mechanical and chemical } \\
\text { means of oral hygiene, } \\
\text { the observance by } 100 \% \\
\text { of the studied nursing } \\
\text { team, the non- } \\
\text { involvement of infections } \\
\text { of the respiratory system } \\
\text { of oral origin. }\end{array}$ & $\begin{array}{c}\text { Revista do } \\
\text { instituto de } \\
\text { ciências da } \\
\text { saúde. (2015) }\end{array}$ \\
\hline 8 & $\begin{array}{c}\text { Silva GS, } \\
\text { Gonçalves } \\
\text { FAF, Bueno } \\
\text { BRM, et al. } \\
\text { [4] }\end{array}$ & $\begin{array}{l}\text { Oral care in } \\
\text { mechanically } \\
\text { ventilated } \\
\text { patients: } \\
\text { Knowledge of } \\
\text { nurses from a } \\
\text { teaching } \\
\text { hospital }\end{array}$ & 22 nurses & $\begin{array}{l}\text { Nurses know the } \\
\text { recommended oral } \\
\text { hygiene measures. The } \\
\text { complicating factors } \\
\text { found were the lack of } \\
\text { trained people }(21.7 \%) \text {, } \\
\text { lack of time }(16.7 \%) \text { and } \\
\text { bureaucratic work (15\%). } \\
\text { However, there are still } \\
\text { gaps with regard to } \\
\text { products and materials } \\
\text { used in oral hygiene. }\end{array}$ & $\begin{array}{c}\text { Enfermagem } \\
\text { em foco } \\
\text { (2017) }\end{array}$ \\
\hline
\end{tabular}

Chart 01 refers to the authors, thematic of the articles, year of publication, number of sample and results / conclusion and magazine / year. Of the eight studies selected, four were found in the PubMed database, two of the articles from SCIELO and two from Google Scholar. A critical synthesis of the main results was carried out, in the period from 2015 to 2020 that deal with oral care in ICU patients, considering 3 aspects: the perception of dental professionals about oral hygiene in the ICU; the perception of the nursing and multidisciplinary team about the importance of oral health in the ICU; absence / presence of protocols for teams working in the ICU for optimal hygiene.

\section{DISCUSSION}

This research links Nursing and Dentistry through the articles described in chart 01 with regard to oral care, disease prevention (nosocomial infections), in addition to the benefits arising from the presence of the dentist in care protocols and in guidance and assistance in ICU. The presence of the Dental Surgeon helps in the provision of oral care in addition to contributing to the training of the Nursing team and in carrying out specific care concerning the Dental Surgeon, avoiding the proliferation of pathogens and the emergence of Ventilator-associated pneumonia (VAP). [17]

The risk of developing nosocomial pneumonia (PN) is high when the patient is on mechanical ventilation (MV), which can prolong the hospital stay from 6 to 10 days. [3], [7], [8] One of the methods for the prevention of NP is the adequacy of the oral environment, avoiding the spread of infectious agents in the oropharyngeal region, by 
Relationship Between Nursing and Dentistry in Patient Care in Intensive Care Unit: An Integrative Literature Review

mechanical and pharmacological methods, however the presence of the endotracheal tube that makes access difficult. [4], [8]

Intubation makes it impossible to close the mouth, leading to dryness and an increase in microorganisms in the biofilm, which reach the respiratory tract by aspirating the contents of the oropharynx and oral secretions that leak from the tracheal tube. [5], [22] The VAP may occur in the initial period of hospitalization, when the cause is related to oropharyngeal bacteria, such as Streptococcus pneumoniae, S. aureus, Haemophilus influenzae, Enterobacteriaceae spp, low-resistance microorganisms and may occur in the later period of hospitalization and by gram-negative bacteria from greater resistance, such as P. aeruginosa, Acinetobacter spp. and S. aureus. [23], [24]

The early stage of VAP is related to gram positive and low resistance bacteria, showing a significant correlation between oral bacteria and VAP. oral health care plays a very important role in preventing pneumonia in patients on mechanical ventilation. In addition to oral interventions, there is a package of multidisciplinary measures for the prevention of VAP: Guideline for Prevention of Nosocomial Pneumonia, [25] which recommends some parameters, some of which are: bedside elevation is recommended to reduce bronchoaspiration; oral hygiene reducing the colonization of microorganisms from the oropharynx and stomach, the aspiration of secretions to the respiratory tract and the reflux of the gastrointestinal tract; subglottic aspiration; care with the mechanical ventilator and cuff pressure (cuff). [26]

Oral hygiene measures in the prevention of VAP follow the mechanical and chemical principles, through tooth brushing, cleaning the mucosa with gauze in edentulous patients, brushing the back of the tongue and scraping supragingival tartar; use of antibacterial solutions such as $0.12 \%$ chlorhexidine for intraoral use and decontamination of the endotracheal tube, [12], [22] enzymatic solutions, hydration and humidification of the lips and mucosa through salivary substitute. [21], [23] The implementation of a simple protocol improves the quality of oral health care for patients admitted to the ICU, to standardize and reduce VAP rates, [15], [17] since oral hygiene methods they vary between the intensive care units and professionals leave something to be desired in oral hygiene, aiming only at the patient's hospitalization. [18]

The presence of protocols, materials and training substantially affects the quality of care provided by the Nursing team as it has a greater role in oral care for ICU patients. [19] Even having knowledge of the importance and benefits of oral health and this activity being routine, nursing demands training on oral hygiene and continuing education. [4] it is necessary to take into account the lack of training on the part of the health team on oral hygiene care, this reality can be verified through studies in the area. In one of these surveys, it was found that $80.5 \%$ of the health team, composed of nurses and technicians, stated that they had never participated in any course or training to perform oral hygiene for hospitalized patients. Such data demonstrates a possible deficit in the oral care of these patients, and consequently, there is once again the need for the dental surgeon to be present in the health team, so that in this way it contributes substantially to the care and comprehensive care. of patients in the ICUs. [19]

Unfortunately, the oral cavity is considered disadvantaged in patients in certain intensive care units, as the greatest attention is directed to the reason why the patient is hospitalized, coupled with this, the absence of a professional with specific scientific technical knowledge of the oral cavity for assisting the nursing team that is directly involved in the hygiene of these patients, further corroborates this situation. However, it is necessary to highlight that only the simple accumulation of biofilm can develop serious complications that can even lead to death, such as in cases of mechanical ventilation, where the tube can carry bacteria present in the oral cavity to the lungs, favoring the installation of pneumonia. [4], [13], [15]

As professionals of a multidisciplinary team and aiming to reduce complications and enable quality of life, the dental surgeon and nurse must be continuously working in an interdependent and harmonic way when it comes to oral hygiene of patients unable to self-care, since hygiene in certain locations of the mouth, they are considered difficult to perform, especially in the posterior teeth region in patients with orotracheal intubation. When specific techniques and care are not properly taught to the team, the task becomes even more complex for those who perform it. Consequently, oral complications can arise and interfere with systemic conditions, reducing turnover within the ICU and increasing the costs of hospital treatments. [15], [17], [27]

It is known that the implementation of guidelines for oral hygiene is necessary for assertive assistance. The joint work of the intensive care nurse and dental surgeon promotes benefits for the care process, as well as, a careful inspection of the oral cavity, which provides a better investigation for diagnosis and planning of appropriate care. In view of the observance of professionals, in addition to the early detection of opportunistic infections, there is a likelihood of prophylaxis of respiratory infections beginning in the oral cavity. Thus, a specific therapeutic plan is developed for each patient, as the vision of dentistry and nursing care includes positive points. [17], [18]

International Journal of Research -GRANTHAALAYAH 
Gabriel Lucas Pereira Guimarães, Giovanna Nascimento Mendes, Quéren Gabriele Cunha Silva, Samylly dos Santos Santana, Nahida Sarhan de Lima, Gabriele Angélica Silva Santos, Franciel Alves Nascimento, Marcela Barbosa Peixoto, Tiago

José Silva Oliveira, and Ivair Tavares Junior

The presence of the Dental Surgeon with the Nursing team or multidisciplinary team contributes positively to the general health status of patients in the ICU, allowing for better monitoring in hospitalizations, as well as enabling a better coping with oral health problems, filling in the gaps that may exist with regard to the use of materials and products consequently contributing to care and care practices. [4], [17] When the hospital has a complete care team and the relationship between dentist and nurse is effective, the patient is richly benefited, because with a wellsanitized mouth, free from injuries and opportunistic infections, favors a better prognosis. [26], [27]

The necessary competencies for an efficient care, it is done through the development of educational practices, it is valid that there is a constant update on the theme and its actions within the intensive care unit. From this perspective, it is assumed that the quality of the health service increases to a high degree, since there is a specific deficit in care for each patient found. [4]

\section{CONTINUING EDUCATION AS A MULTIPROFESSIONAL FACILITATOR IN ICU CARE}

Continuing education (CE) in the ICU environment for the multiprofessional team, is necessary since the management with hospitalized patients always requires updates in view of the high complexity of this sector, involving technological equipment and the interrelation in the multiprofessional team. There are several advantages when establishing CE programs, as it covers interdisciplinarity providing communication between health professionals. The objective of $\mathrm{CE}$, in addition to providing greater safety for the patient and the professional team in the stages of planning, evolution and prognosis, also brings greater security in the prevention of VAP, in addition to qualifying care in humanized patient care. Professional improvement, through CE is an educational process and in the ICU, it takes place through the training and updating of the team's daily knowledge. [28], [29]

$\mathrm{CE}$ is a viable path that provides the interrelationship between nursing and dentistry, which presupposes an improvement in the services provided to ICU patients who require oral care. Enabling the development of new care skills and knowledge. [4], [17], [19], [21] In view of this, it is necessary to disseminate knowledge, through training courses aimed at dental care, in order to minimize complications resulting from the absence or inadequacy of the assistance provided, since professionals have little knowledge about the subject of hospital dentistry and their experiences, and part of this is related to the lack of knowledge about dentistry in the hospital context. It is worth mentioning the importance of encouraging the adherence of these professionals to training courses since the lack of knowledge in this area directly influences the dimension of care provided to the client, who will not be assisted in a comprehensive and holistic manner. [18]

In this sense, it is also worth emphasizing the importance of CE through training courses and in-hospital training for the Nursing team, as it has some services and care that are essential to patients on mechanical ventilation, in addition, such professional improvement allows for improvement in the care process guaranteeing knowledge, attitudes and skills that can lead to a significant evolution in the improvement of patients in ICU. [4]

The multidisciplinary team with access to CE programs, has learning advantages and acquires important skills for their work. The promotion of CE reveals the institution's commitment to the need for constant updates to improve the assistance of its professionals. [21] Among the professional areas active in the ICU, nursing is the area most involved in continuing education programs. According to ORLANDINI GM, et al. (2012) [30] in their descriptive exploratory study, through an interview found that $50 \%$ of nurses and $56.4 \%$ of nursing technicians, stated that the hospital they work for promotes CE programs, however they reported on the issue of oral hygiene and the prevention of VAP are not a topic of CE, and do not receive adequate training, in addition to the absence of standardized measures and protocols in oral care. The integration of the Dental Surgeon in the ICU leads to a better clarification and standardization of oral care by the Nursing team, as it is the team responsible for performing oral hygiene, however the presence of the Dental Surgeon needs to be a mandatory reality in the provision of hospital care. [12], [18], [30]

\section{FINAL CONSIDERATIONS}

The clinical condition of patients hospitalized in the ICU makes them need daily care with regard to oral hygiene, in this sense the joint performance of the professionals mentioned here contributes to a better provision of care, 
reducing risk factors and enabling a process of cures faster, taking into account oral health and its relationship with possible nosocomial infections in the hospital environment. The importance of CE in both professions is emphasized, which provides training and effectiveness in ICU care, in addition to strengthening communications and the harmonious relationship between nursing and dentistry aimed at the health of assisted patients.

\section{SOURCES OF FUNDING}

This research received no specific grant from any funding agency in the public, commercial, or not-for-profit sectors.

\section{CONFLICT OF INTEREST}

The author have declared that no competing interests exist.

\section{ACKNOWLEDGMENT}

None.

\section{REFERENCES}

[1] Cruz MK, Morais TMN, Trevisani DM. Clinical assessment of the oral cavity of patients hospitalized in an intensive care unit of an emergency hospital. Rev Bras Ter Intensiva. 2014. Dec; 26(4): 379-383.

[2] Axelsson P, Lindhe J. Effect of controlled oral hygiene procedures on caries and periodontal disease in adults. J Clin Periodontol. 1978;5(2):133-151.

[3] Ory J, Mourgues C, Raybaud E, et al. Cost assessment of a new oral care program in the intensive care unit to prevent ventilator-associated pneumonia. Clin Oral Investig. 2018; 22(5):1945-1951.

[4] Silva GS, Gonçalves FAF, Bueno BRM, et al. Cuidados bucais em pacientes ventilados mecanicamente: Conhecimento de enfermeiros de um hospital escola. Enfermagem em Foco [Internet]. 2017 [cited 2020 Jul 14];8(4) Available from: http://revista.cofen.gov.b-r/index.php/enfermagem/article/view/932

[5] Cambraia ES, Guedes, ML, Rocha, RR. Atuação do cirurgião-dentista em unidades de terapia intensiva na prevenção da pneumonia associada à ventilação mecânica. Revista do Cromg. 2015. 16(2).

[6] Brito LFS, Vargas MAO, Leal SMC. Higiene oral em pacientes no estado de síndrome do déficit no autocuidado. Revista Gaúcha de Enfermagem [Internet]. 2007 [cited 2020 Jul 20];28(3) Available from: https://www.seer.ufrgs.br/RevistaGauch-adeEnfermagem/article/view/4682/2610

[7] Pires AF, Santos BN, Santos PN, et al. Prevalência dos diagnósticos de enfermagem segundo NANDA em pacientes internados em unidade de terapia intensiva: Um relato de experiência. Rev Rede de Cuidados em Saúde. [Internet]. $2016 \quad$ [cited 2020 Aug 11];10 Available from: http://publicacoes.unigranrio.edu.br/index.php/rcs/article/view/2626/1507

[8] Vilela MCN, Ferreira GZ, Santos PSS, et al. Cuidados bucais e pneumonia nosocomial: revisão sistemática. Einstein. 2015; 13(2): 290-296.

[9] Rabelo D, de Queiroz CI, da Silva SPS. Atendimento odontológico ao paciente em unidade de terapia intensiva. Arquivos Médicos dos Hospitais e da Faculdade de Ciências Médicas da Santa Casa de São Paulo. [Internet]. 2010 [cited $2020 \quad$ Jul 20]; $55(2), \quad 67-70 . \quad$ Available from: http://189.125.155.35/index.php/AMSCSP/article/view/337

[10] Sociedade Brasileira de Cardiologia. 3a diretriz de avaliação cardiovascular perioperatória da sociedade brasileira de cardiologia. Arquivos brasileiros de cardiologia [Internet]. 2017 [cited 2020 Aug 11]; 109 Available from: https://www.scielo.br/pdf/abc/v109n3s1/pt_0066-782X-abc-109-03-s1-0001.pdf

[11] Miranda AF. Odontologia Hospitalar: Unidades de Internação, Centro Cirúrgico e Unidade de Terapia Intensiva. RCO. 2018; 2(2), 5-13.

[12] Conselho federal de odontologia. Bolsonaro veta projeto que garante assistência odontológica a pacientes em regime de internação hospitalar [Internet]. http://website.cfo.org.br/; 2019 Jun 05 [cited 2020 Jun 25]. 
Gabriel Lucas Pereira Guimarães, Giovanna Nascimento Mendes, Quéren Gabriele Cunha Silva, Samylly dos Santos Santana, Nahida Sarhan de Lima, Gabriele Angélica Silva Santos, Franciel Alves Nascimento, Marcela Barbosa Peixoto, Tiago José Silva Oliveira, and Ivair Tavares Junior

Disponivel em: http://w-ebsite.cfo.org.br/bolsonaro-veta-projeto-que-garante-assistencia-odontolog-ica-ap-acientes-em-regime-de-internacao-hospitalar/.

[13] Lima AKMMN, Cabral GMP, Araújo TLC, et al. Percepção dos profissionais que trabalham na Unidade de Terapia Intensiva (UTI) quanto à inclusão do cirurgião-dentista na equipe. Full Dent Sci. 2016; 7(28):72-5.

[14] Souza MT, Silva MD, Carvalho R. Revisão integrativa: o que é e como fazer. Einstein, 2010; 8(1 Pt 1):102-6.

[15] Blum DFC, Silva JAS, Baeder FM, et al. A atuação da Odontologia em unidades de terapia intensiva no Brasil. Rev. bras. ter. intensiva. 2018; 30(3): 327-332.

[16] Ory J, Raybaud E, Chabanne R, et al. Comparative study of 2 oral care protocols in intensive care units. Am J Infect Control. 2017; 45(3), 245-250.

[17] Blum DFC, Munaretto J, Baeder FM, et al. Influence of dentistry professionals and oral health assistance protocols on intensive care unit nursing staff. A survey study. Rev Bras Ter Intensiva. 2017; 29(3): 391-393.

[18] Feitosa DAS, Souza HTN, Alencar AM, et al. Percepção dos profissionais atuantes nas UTI's quanto à importância de condutas de saúde bucal. Investigação Científica [Internet]. 2019 [cited 2020 Jul 7]; 24:328333. Disponivel em: http://www.seer.upf.br/index.ph-p/rfo/article/view/9452/114115217

[19] Oliveira LS, Bernadino IM, Silva JAL, et al. Conhecimento e prática do controle de higiene bucal em pacientes internados em unidades de terapia intensiva. Revista da ABENO [Internet]. 2015 [cited 2020 Jul 7]; 15:29-36. Available from: http://revodo-nto.bvsalud.org/scielo.php?pid=S1679-59542015000400005\&script=sci_arttext

[20] Silva JL, O El Kadre GD, Kudo GA, et al. Oral Health of Patients Hospitalized in the Intensive Care Unit. J Contemp Dent Pract. 2016 Feb 1;17(2):125-9.

[21] Matos MPSO, Silva RFG. A eficácia da higiene bucal na prevenção de doenças respiratórias em pacientes internados na UTI Adulto do Pronto Socorro 28 de Agosto. Revista do Instituto de Ciências da Saúde [Internet]. 2015 [cited 2020 Jul 7]; 33:344-346. Available from: https://www.unip.br/presencial/comunicaca-o/publicacoes/ics/edicoes/2015/04_out-dez/V33_n4_2015_p344a346.pdf

[22] Liao YM, Tsai JR, Chou FH. The effectiveness of an oral health care program for preventing ventilatorassociated pneumonia. Nurs Crit Care. 2015, 20(2), 89-97.

[23] Assis C. O atendimento odontológico nas UTIs. Rev. bras. odontol. 2012. 69(1), 72.

[24] Nair GB, Niederman, MS. Ventilator-associated pneumonia: present understanding and ongoing debates. Intensive Care Med. 2015. 41(1), 34-48.

[25] Tablan OC, Anderson LJ, Besser R, et al. Guidelines for preventing health-care--associated pneumonia, 2003: recommendations of $\mathrm{CDC}$ and the Healthcare Infection Control Practices Advisory Committee. MMWR Recomm Rep. 2004. 53(RR-3):1-36.

[26] Chicayban LM, Terra ELVS, dos Santos Ribela, et al. Bundles de prevenção de pneumonia associada à ventilação mecânica: a importância da multidisciplinaridade. Biol Saúde. 2017. 7(25).

[27] Batista AS, Siqueira JSS, Silva Jr A, et al. Alterações orais em pacientes internados em unidades de terapia intensiva Rev. bras. Odontol, 2014. 71 (2): 156-9.

[28] Ribeiro BCO, souza RG, Silva RM. A importância da educação continuada e educação permanente em unidade de terapia intensiva-revisão de literatura. Revista de Iniciação Científica e Extensão, 2019. 2(3): 167-175.

[29] Souza LP, lima MG. Educação continuada em unidade de terapia intensiva: revisão da literatura. Journal of Health \& Biological Sciences, 2015. 3(1), 39-45.

[30] Orlandini GM, lazzari CM. Conhecimento da equipe de enfermagem sobre higiene oral em pacientes criticamente enfermos. Revista Gaúcha de Enfermagem, 2012. 33(3), 34-41. 